University of Nebraska - Lincoln

DigitalCommons@University of Nebraska - Lincoln

Textile Society of America Symposium

Proceedings

Textile Society of America

2020

By Land and by Sea: Displaced Samplers Reveal Women on the Move

Lynne Anderson PhD

University of Delaware, lynneandrs@gmail.com

Follow this and additional works at: https://digitalcommons.unl.edu/tsaconf

Part of the Art and Materials Conservation Commons, Art Practice Commons, Fashion Design Commons, Fiber, Textile, and Weaving Arts Commons, Fine Arts Commons, and the Museum Studies Commons

Anderson, Lynne PhD, "By Land and by Sea: Displaced Samplers Reveal Women on the Move" (2020). Textile Society of America Symposium Proceedings. 1132.

https://digitalcommons.unl.edu/tsaconf/1132

This Article is brought to you for free and open access by the Textile Society of America at DigitalCommons@University of Nebraska - Lincoln. It has been accepted for inclusion in Textile Society of America Symposium Proceedings by an authorized administrator of DigitalCommons@University of Nebraska - Lincoln. 


\title{
By Land and by Sea: Displaced Samplers Reveal Women on the Move
}

\author{
Lynne Anderson, Ph.D. \\ lynneandrs@gmail.com
}

The archival record for women throughout much of European and American history is sparse. Where it exists, the women were usually aristocratic by birth or rebellious in life. For the "middling sort," women's lives are better documented by investigating the things they made and used - the material culture of daily life. Because all girls were routinely taught to sew, it is sometimes possible to reveal the otherwise unseen lives of girls and women by examining and researching the needlework projects they left behind.

Learning to sew and embroider were standard components of female education, taught in public and private schools at all socio-economic levels. According to sampler scholar Betty Ring, up until the mid-nineteenth century any girl who had received even the slightest bit of education would have embroidered at least one needlework sampler as part of their schooling. ${ }^{1}$ A girl's first sampler demonstrated she had learned to sew a few different stitches, copy the alphabet, and "write" her own name, albeit with needle and thread, not pen and ink. If instruction continued past these basics, subsequent embroideries might reveal more advanced needlework techniques, attention to graphic elements such as floral motifs and rural scenes, and the girl's expanding grasp of literacy and literature. Each sampler was considered a significant accomplishment - by the girl herself, her teacher, her family, and even potential suiters. Embroidered samplers were treasured objects - framed and displayed in the home or tucked away safely for posterity. If parents moved to new locations, their daughters' needlework traveled too - packed carefully within the folds of a dress or laid on top of the extra bedding. When women joined husbands to start a new home or migrated westward seeking a new life, many chose to bring along their girlhood embroideries - objects embedded with memories of the home they were leaving behind, their childhood friends, and the family members they might never see again.

By Land and by Sea is the story of two nineteenth-century schoolgirl samplers found thousands of miles from their places of origin, resting comfortably within the textile collection of the Oregon Historical Society. ${ }^{2}$ It is a narrative that probes the objects themselves, and the girls who stitched them, to uncover the hidden stories of the samplers and their makers. The narrative brings to life two pioneering women, revealing when and how their girlhood needlework traveled "by land and by sea," packed safely within their makers' trunks amidst other treasured belongings and the necessities for starting a new home. One of the women died in route, never realizing the family dream of starting fresh in Oregon Territory - but her needlework made the trip unscathed. The fact that both women felt their schoolgirl samplers were important to include when traveling to the other side of the American continent is a testament to the samplers'

\footnotetext{
${ }^{1}$ Betty Ring, Girlhood Embroidery: American Samplers \& Pictorial Needlework 1650-1850, Vol. 1 (New York: Alfred A. Knopf, 1993), xvii.

${ }^{2}$ Both samplers were included in a 2017 sampler exhibition hosted by the Oregon Historical Society in Portland Oregon entitled 'Use Well Your Time While in Your Prime': Samplers from the Oregon Historical Society Collection. Curated by Helen Fedchek, the exhibit ran from July 30 through November 26, 2017.
} 
perceived value and an indication of the importance of needlework in the women's lives.

\section{Mary S. Garrison, 1838}

Mary Garrison stitched an attractive and well-balanced sampler with a large central motif, three verses, a "signature," and small mirror image motifs running vertically between the text and a wide three-sided floral arcade border (Figure 1). When Mary signed her sampler, she provided four helpful pieces of information, making the task of identifying her fairly straight forward. In black thread Mary told us her name (Mary S. Garrison); when she was born ("in the year 1823 Nov $\left.30^{\text {th" }}\right)$; the year in which she made her sampler (1838); and how old she was when she created this testimony to her needlework skill ("in the $15^{\text {th }}$ year of her age").

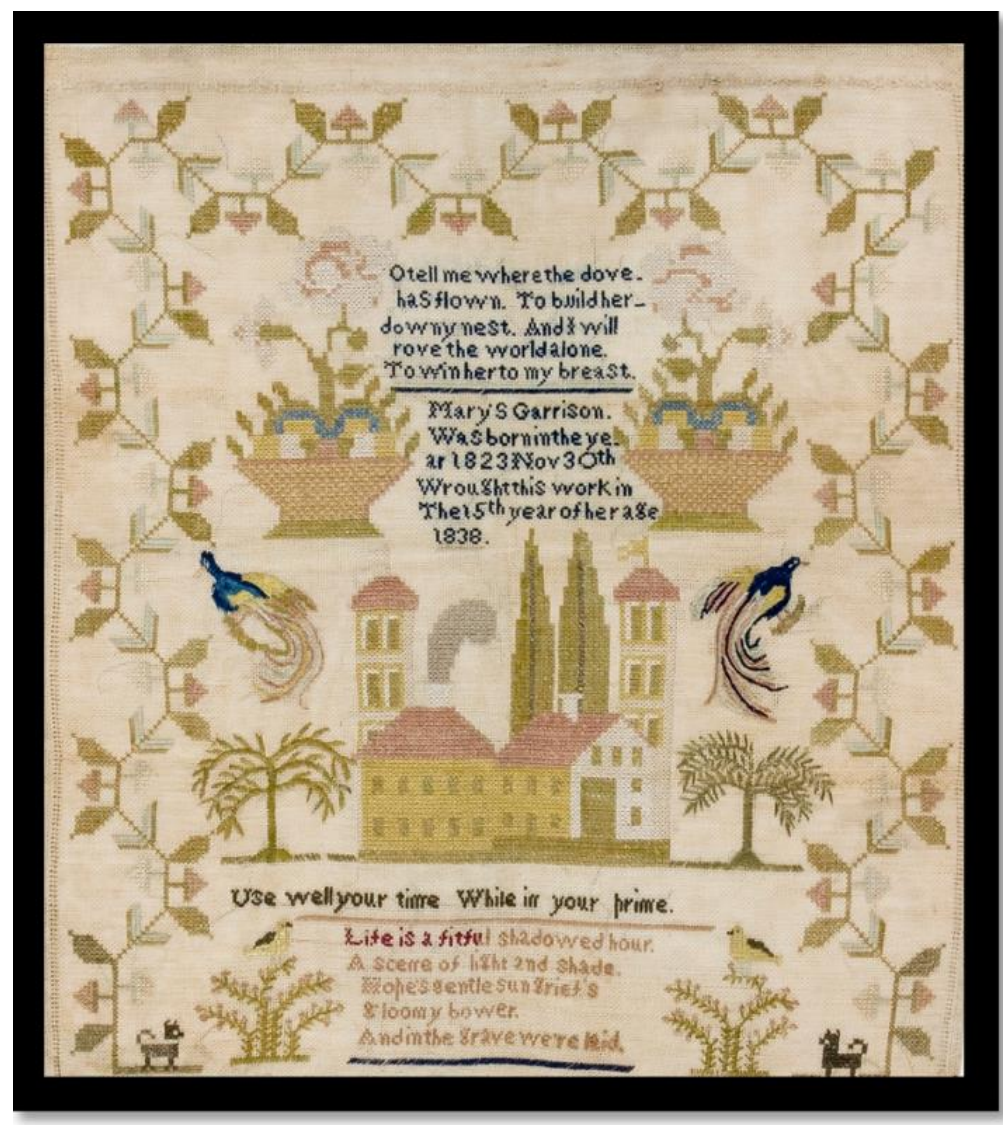

Figure 1. Sampler made by Mary S. Garrison in 1838. Courtesy of the Oregon Historical Society

A small amount of genealogical research revealed that Mary's full name was Mary Scott Garrison, and that she was born in Fairfield, Franklin County, Indiana to Mary and John Garrison, both originally from New Jersey. Mary had at least one living sibling, a younger brother, also named John, who was born in 1830. In the 1840 census Mary's mother is listed as the head of the Garrison household, which suggests Mary's father had died prior to $1840 .{ }^{3}$

\footnotetext{
${ }^{3}$ Online sources used to identify Mary Scott Garrison include genealogical family trees and databases at ancestry.com; vital records for Franklin County, Indiana; and the U.S. federal census records for 1840 and 1850.
} 
In addition to her genealogical information, Mary stitched three verses, each reflecting nineteenth century expectations for young women's religious and moral development. The first verse, beginning "O tell me where the dove has flown," advocates living a peaceful life through closeness with God. It is the first stanza of a six-stanza hymn known as the Dove of Peace. The second verse is an aphorism "Use well your time while in your prime." It is the second line in a set of seven similar recommendations for appropriate living, published in an 1806 Spelling Book authored by John Comly (1773-1850). Comly was a well-known Quaker educator living in Pennsylvania who published a number of books for teaching reading, writing, and grammar, each with full or partial verses compiled from many, usually unattributed, sources. The final verse on Mary's sampler, begins "Life is a fitful shadowed hour." It is the first stanza of a four-stanza poem entitled "Mutability of Earthly Joy" - a frequent theme for girls' samplers reminding them of the transience of pleasure and fragility of life. ${ }^{4}$

In the center of Mary's sampler is a colorful town scene with two buildings, two towers, two poplar trees in back, two willow trees in front, and two spectacular birds with colorful flowing tails. Although it is tempting to think that Mary is sharing a glimpse into her hometown of Fairfield, it is more likely the buildings were copied from commercially available patterns. And the birds are certainly not indigenous to Indiana. The sampler's organization and level of accomplishment, as well as the inclusion of literary verses, indicate Mary Garrison was receiving formal schooling at the time the sampler was made. Furthermore, this piece of needlework is definitely not Mary's first sampler. Although Mary does not indicate where she was going to school in 1838, it is very possible there was a talented needlework teacher in her hometown of Fairfield. It is also possible that Mary spent the year at a girls' boarding school somewhere in Indiana or neighboring Ohio and completed her sampler while living away from home.

In December of 1844 21-year-old Mary Garrison married a neighboring resident of Fairfield. William Masters was a 25-year-old cabinet maker whose family had moved to Indiana from Pennsylvania. By 1850, Mary had given birth to three sons: Lewis Leake Masters in 1846; Samuel Lafayette Masters in 1848; and John Wilbur Masters in $1850 .{ }^{5}$ In the spring of 1852 , Mary, William, and their three sons joined the mass migration of families heading west following the Oregon Trail. ${ }^{6}$ Mary was 28 years old and pregnant with their fourth child. The overland trip from the Missouri River to the Willamette Valley in Oregon was a little more than 2000 miles and usually took about six months to complete. And it wasn't inexpensive. For a family of four the cost was about $\$ 1000$, approximately $\$ 34,000$ in today's dollars. ${ }^{7}$

Emigrants on the Oregon Trail usually banded together into parties or "companies" for mutual assistance and protection. These parties often consisted of relatives or persons from the same hometown who chose to travel together. And this was true for Mary and William, who were joined by Mary's 22-year-old brother John. To our knowledge, Mary did not keep a diary during

\footnotetext{
4 To read the complete verses, see: (a) "Dove of Peace" at hymnary.org; (b) John Comly, Spelling Book, Philadelphia, 1806, p. 23 at Hathitrust.org; and (c) "Mutability of Earthly Joy" at hymnary.org.

${ }^{5}$ As recorded on the 1850 U.S. Federal Census records.

${ }^{6}$ The names of both William Masters and Mary Garrison Masters appear on the website Emigrants to Oregon in 1852 at oregonpioneers.com/1852_JQ.htm

${ }^{7}$ Information from the website officialdata.org by Ian Webster (https://www.officialdata.org/us/inflation/1852)
} 
the trip westward, however many women $\operatorname{did} .{ }^{8}$ From these records we learn that adults usually got up before dawn, had a simple breakfast of coffee and bread, and then readied the wagons for an early morning departure. In the words of Alice Rockefeller, who traveled west from Indiana as a girl, "We crept along slowly...We slept in that wagon and I never got up until we were travelling. We had some seamless sacks of soda crackers in this wagon. I remember making breakfast out of these soda crackers, at the same time looking back at my mother and talking. I remember one morning we started very early; we had camped that night without water; the stocks were very dry. We had traveled several miles since starting that morning. All of a sudden an ox whirled out of the team and started to run. They ran quite a distance before they were stopped. Men said they smelled water and we soon came to water... When night came on and our day's drive was finished, our teams circled around with their wagons placing the wagon's tongue up against the next wagon's and all around, making a circle or enclosure so we had a complete circle. Then every man would attend to his horses and guards would take turns watching; others got wood and water, placed tents, and the horses would eat their fill of the long grass; and then the men would tie each by his own wagon, but still the men would patrol the country near us. In order to get water some days the drive would be short, others longer but we always stopped when we reached water." 9 Evening meals were also usually quite simple, often tea and boiled rice with some bacon, dried beef, or codfish.

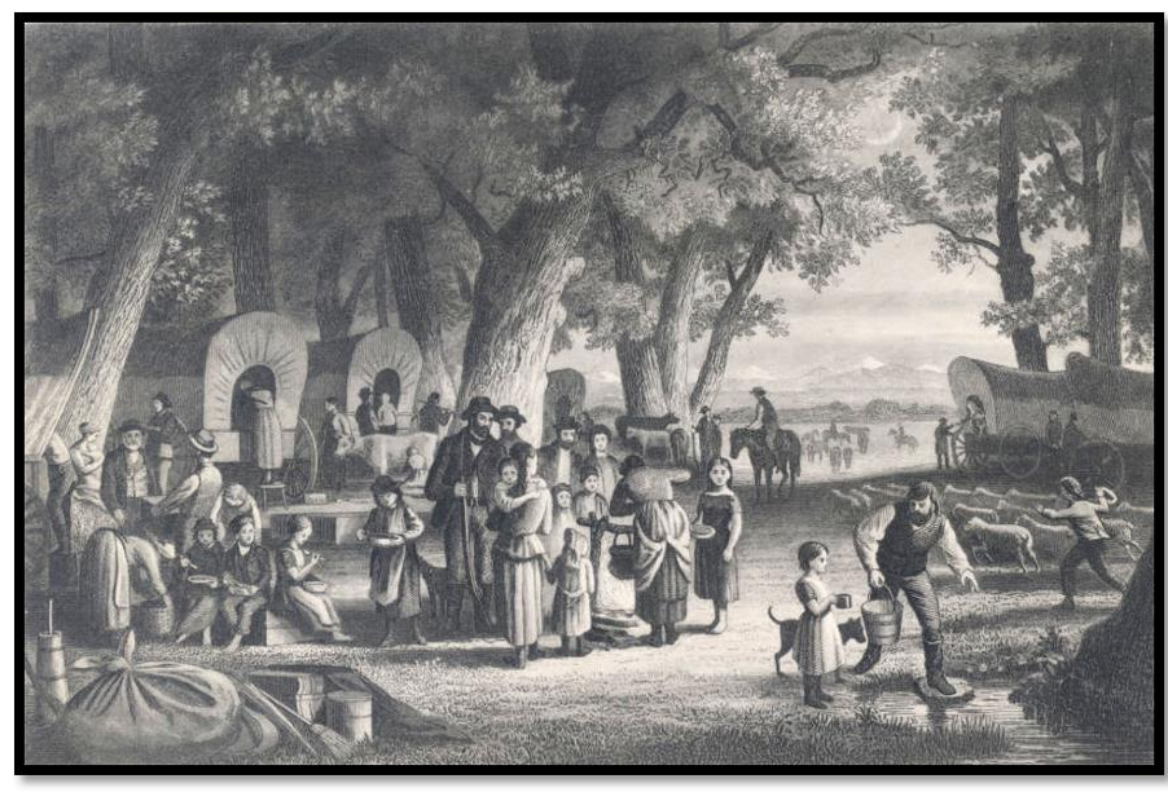

Figure 2. "Oregon Trail Emigrant Camp" by H. Wilcox \& S. Sartain Courtesy Oregon Historical Society Research Library

Wagon trains tried to travel about 15 miles a day, but the availability of water, inclement weather, illness, and difficult terrain influenced the distances they could actually achieve. Mary Woodland wrote this to her parents in Ohio: "One day we went ten miles and locked our wagons thirty-three times then comes the wild sage brush and grease wood dust and sand. If you ride in the wagon you are almost suffocated with the dust and heat to get out and walk you must follow in the road after the teams ... or else have your clothes torn and your flesh scratched with the

\footnotetext{
${ }^{8}$ For example, see Emigrant Diaries and Journals at http://www.oregonpioneers.com/diaries.htm.

${ }^{9}$ Alice Rockefeller, Alice Rockefeller Reminiscences. Online at: http://www.oregonpioneers.com/rockflr.htm
} 
briery wood. I hope I never see another bush of wild sage as long as I live for hundreds of miles that nasty brush is everywhere day after day we traveled as our teams were getting weaker our provisions lower and ourselves wishing we were through then came the Rocky Mountains. They are sublime lofty columns of clean rock not a shrub nor sphere of grass to be seen." 10 Mary and William's wagon train followed the southern route to Oregon, also known as the Applegate Trail. It separated from the main route just west of Fort Hall in Idaho, then passed through Nevada and a bit of northern California before heading north into Oregon. On July 5, 1852, while traveling through Nevada Territory, Mary gave birth to a daughter, her fourth child. The baby was named Mary Nevada Masters, in honor of Mary's mother, Mary Garrison, and to commemorate the place of her birth.

In the history of emigration on the Oregon Trail, the year 1852 "stands out as the year of illness and death." 11 For most, the cause of death was cholera. In September of 1852 Mary Garrison Masters was two months shy of her 29th birthday. She and William were nearing the completion of their arduous trek across two thirds of the continent when tragedy struck their wagon train. Shortly after entering "Oregon Territory" their six-year-old son Lewis fell ill with cholera and died on September 1, 1852. Mary, still recovering from the rigors of pregnancy and childbirth, also fell ill and died six days later on September 7. Mary's newly born daughter, Mary Nevada, followed her on September 24, having only reached the age of two months and 19 days. ${ }^{12}$

William Masters and his remaining family carried on, eventually settling at the northern end of the Willamette Valley in the newly emerging city of Portland, Oregon. Although Mary Garrison Masters never reached Portland, she, her son Lewis Leake Masters, and infant daughter Mary Nevada Masters are commemorated in Portland's Lone Fir Pioneer Cemetery with similar markers of hand carved, flat, rounded stone. ${ }^{13}$

\footnotetext{
${ }^{10}$ Mary Woodland, Woodland Letters. Online at http://www.oregonpioneers.com/Woodland_Letters1852.htm

${ }^{11}$ Emigrants to Oregon in 1852. Online at oregonpioneers.com/1852

${ }^{12}$ Cholera, transmitted via unsanitary conditions, could kill its victims quickly. Someone may feel fine in the morning, be in agony with stomach cramps and diarrhea by noon, and dead from severe dehydration by night. A cholera pandemic raged globally from 1846 to 1860 and it is estimated that more than 12,000 individuals died from cholera while migrating to California, Oregon, and Utah in the years 1849 to 1855.

${ }^{13}$ Mary's sons Samuel Lafayette Masters and John Wilbur Masters survived the overland trip to Oregon and grew to adulthood in Portland. According to U.S. Federal Census records Mary's husband became a successful and wealthy marble worker and later a dry goods merchant. In 1860, William Masters married Martha Cordelia York (18311907), an 1852 Oregon emigrant from Illinois and they had three children.
} 


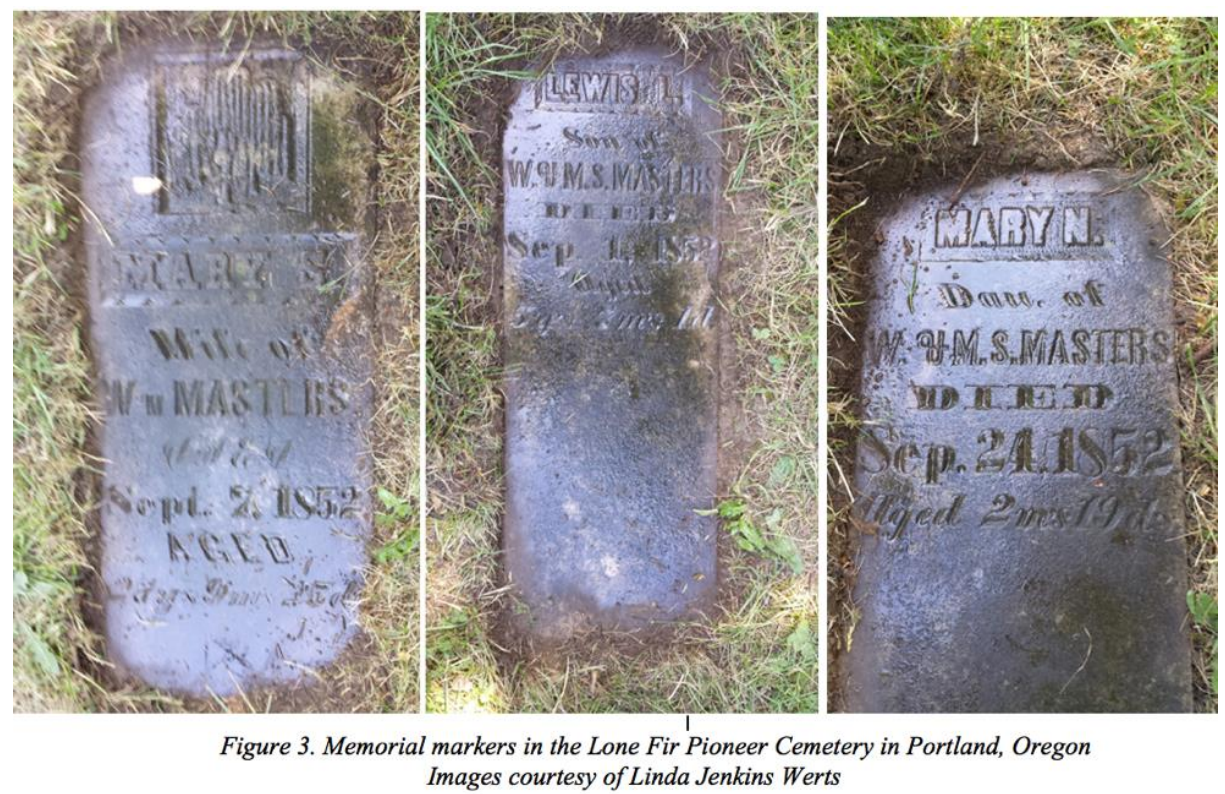

\section{Sarah S. Armstrong, 1836}

In 1836 ten-year-old Sarah S. Armstrong stitched a schoolgirl sampler with multiple alphabets, her signature, a few motifs, and detailed information about her family (Figure 4). Identifying Sarah and locating her hometown was easily accomplished because Sarah chose to embroider a wealth of family details in the lower half of her sampler. From these details we know that Sarah lived in Fletcher, Franklin County, Vermont. Sarah also stitched the names and birth dates of her parents, herself, and her siblings. ${ }^{14} \mathrm{~A}$ bit of online genealogical research revealed additional details. Sarah's father Ira Armstrong was born to parents Reuben and Sarah Armstrong, and the family had moved to Fletcher from Bennington, Vermont in $1795 .{ }^{15}$ Sarah's mother, Lucy Boynton, was born in Massachusetts to Abiel Boynton and Lois Raymond, and she moved with her family to Vermont in 1818. Sarah's parents were married in Fletcher by the local Justice of the Peace, Elias Bingham, on October 1, 1820. ${ }^{16}$ Their first child, Reuben, was born a little more than two months later, followed by another child every three years until 1829. Ira inherited the family farm after his father's death in 1827 and census records indicate the farm was successful, with real estate valued at $\$ 7000$ in 1850 and $\$ 8000$ in 1860. Ira was appointed constable for the town in 1818 and represented Fletcher in the Vermont General Assembly four times. ${ }^{17}$

\footnotetext{
${ }^{14}$ Missing is the birth of Sarah's youngest sister Miriam Armstrong, born June 22, 1840, four years after Sarah completed her needlework. C. H. Boynton and John F. Boynton, The Boynton Family: A Genealogy of the Descendants of William and John Boynton (Boston, 1897), 119.

${ }^{15}$ Ben A. Kingsley, "History of the Town of Fletcher," Vermont Historical Gazetteer, Vol. 2, Pt. 1 (1871), 201.

${ }^{16}$ Vermont Vital Records through 1870 (Boston: New England Historic Genealogical Society, 1870).

${ }^{17}$ Kingsley, 201.
} 


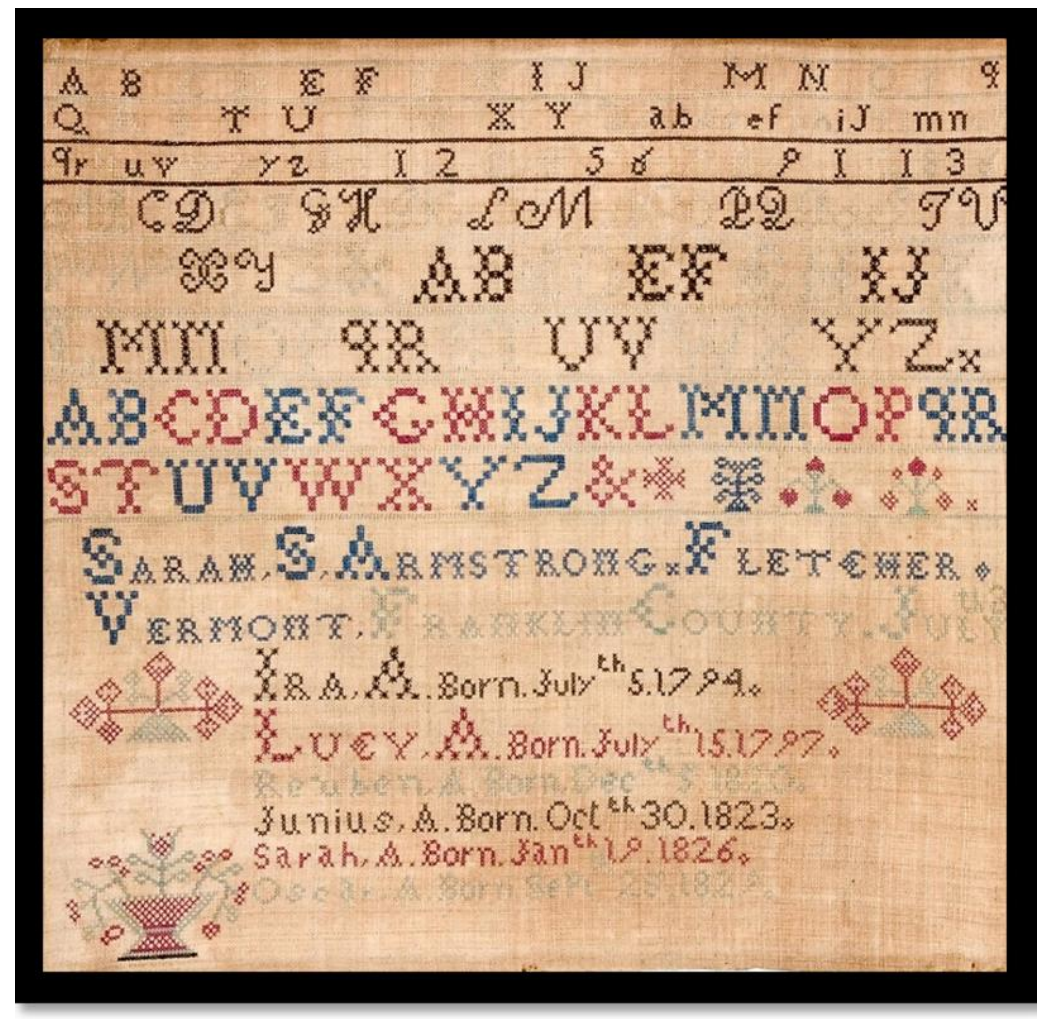

Figure 4. Sampler made by Sarah S. Armstrong in 1836 Courtesy of the Oregon Historical Society

Fletcher is a small township in the southeast corner of Franklin County, which is located in the far northwestern corner of Vermont, close to the Canadian border. Fletcher is about 38 square miles of hilly, often stony land that was home to about 900 people at the time Sarah stitched her sampler. ${ }^{18}$ Sarah undoubtedly attended the local district school, and this was where she probably embroidered her informative, but relatively unsophisticated sampler. Vermont was the first state to formally guarantee a public education for its residents, and through its constitution required that "a competent number of schools ... to be maintained in each town for the convenient instruction of youth." ${ }^{19}$ Sarah was apparently a good student as her parents supported her desire to seek an education beyond that provided in the local grammar school. By 1845, nineteen-yearold Sarah had traveled to neighboring Bakersfield, Vermont to pursue additional education.

The town of Bakersfield, population 1,258 in 1840, came to be known as "old academy town" because it supported multiple schools for students seeking advanced academic preparation. The first was Bakersfield Academical Institution (also just Bakersfield Academy), which was actually two schools: informally known as South Academy which opened in 1840 and North Academy which opened in 1844. School catalogs reveal that in 1845 Sarah S. Armstrong was a student at South Academy, where the highly regarded Jacob Spaulding was headmaster and his wife Mary was both the preceptress for young women and the drawing instructor. ${ }^{20}$ Sarah was one of 191

\footnotetext{
${ }^{18}$ U.S. Federal Census for Fletcher, Franklin County, Vermont.

${ }^{19}$ Vermont Constitution of 1786, Chapter II, Paragraph 38. Quoted in Seth M. Zoracki, "Vermont's Tradition of Education and the Vermont Constitution," Albany Law Review, vol. 67, no. 2 (2006), 584.

${ }^{20}$ Catalogue of the Officers and Students of the Bakersfield Academical Institution for the Year Ending November 1845 (Burlington: Chauncy Goodrich, 1845), 10.
} 
students attending Bakersfield Academy in 1845, 113 "gentlemen" and 78 "ladies." The actual number of students attending the school at any one time, however, was usually much less. In attendance Winter term of that year were 31 students; in Spring, 94 students; in Summer, 49 students; and in Fall, 121 students. ${ }^{21}$ Most of the students were from Bakersfield or other towns in Vermont but some had traveled from states such as Tennessee, Michigan, and Indiana, and a few had crossed into Vermont from Canada. Students were able to board with families in town (room and board, plus wood and washing) for $\$ 1.00$ to $\$ 1.25$ per week.

Bakersfield Academical Institution had two departments - the Classical Department with 60 students in 1845 and the English Department with 187 students. Sarah was enrolled in the English Department which offered a sequence of studies designed for individuals seeking a career in business or teaching. Included were courses such as Grammar, Composition, and Bookkeeping but also Geometry, Trigonometry, Chemistry, and Anatomy. Students were divided into three classes: Senior class, Middle class, and Junior class, with some students also appearing in a fourth class - the French class, of which Sarah was a member. The cost for instruction in any one of the languages (Latin, Greek, French or Spanish) was $\$ 4.00$ per term and there were four terms a year. Studying the "English branches" was $\$ 3.00$ per term, or $\$ 3.50$ for more advanced study. The school also offered courses in vocal and instrumental music, as well as penmanship, drawing, painting, and embroidery. Cost for the latter was $\$ .25$ to $\$ 1.00$ per term. ${ }^{22}$

Sarah's name also appears in the school catalogs for 1847, 1848, and 1849 (suggesting she was probably a student in 1846, however that catalog is missing). By 1847 Sarah had switched her focus and was one of only eight female students listed in the Classical Department, for which 55 students total had enrolled. She was also still a member of the French class, so was clearly carrying a heavy load. Among other academic expectations, the Classical Department offered a rigorous multi-year program steeped in learning the classical languages of Latin and Greek, as well as reading and translating classical literature. Prerequisites for entering were demanding and it is likely that Sarah spent 1845 and possibly 1846 in the English Department preparing for entry to the Classical Department. By 1849 she was one of only two students in the Classical Department's Fourth Year class, ${ }^{23}$ poised to graduate from Bakersfield Academical Institution after five years of rigorous academic study.

While at school Sarah received as fine an education as possible for a woman in Vermont at that time. It is interesting to wonder about her goals and whether she was preparing for something specific. Given her chosen courses of study she was well-prepared to enter business (not a likely choice for women at the time), become a teacher, or enter college. Pursuing a college education was also an unlikely option as few post-secondary schools, including the University of Vermont, admitted women. ${ }^{24}$ Although there were colleges founded exclusively for women, few, in any, could offer a course of study any more rigorous than the one Sarah had just completed. The most likely explanation is that Sarah was preparing to be a teacher. Bakersfield Academical Institution

\footnotetext{
21 Ibid, 12.

22 Ibid, 16.

${ }^{23}$ Catalogue of the Officers and Students of the Bakersfield Academical Institution for the Year Ending November 1849 (Burlington: Chauncy Goodrich, 1849), 7.

${ }^{24}$ According to the University of Vermont's webpage entitled "History and Traditions," the school was one of the first to "defy custom" and admit female students. This did not happen, however, until 1871. Accessed May $29,2020$.
} 
encouraged and supported teaching as a professional option for its graduates, offering special "Teachers' Courses" to "qualify them for their arduous and laborious vocation." 25 The 1847 school catalog states that students pursuing this course of study will be "thoroughly instructed in...the elements of correct school discipline - the best method of teaching particular branches the most successful stimulants to uneducated minds." It continues with the assertion that its instruction "shall be equivalent to that usually received in a Teachers' Institute" and will prepare graduates "to sustain a thorough examination according to the requirements of the late law." 26

Unfortunately, there is no known record suggesting Sarah Armstrong taught school after graduating from Bakersfield Academical Institution. While at the academy, however, she did meet the man she would later marry - Erasmus Darwin Shattuck (1824-1900). Erasmus was a former student at the academy who had returned to the school after graduating from the University of Vermont in Burlington, first as a teacher and then assistant principal - both prior to studying for a law degree in New York. Erasmus and Sarah clearly became acquainted while she was student at the school, probably discovering a shared interest in classical language and literature - among other attractions. On December 27, 1852, two days after Christmas and four days before his $28^{\text {th }}$ birthday, Erasmus Shattuck married 26-year-old Sarah Armstrong at her parent's home in Fletcher. Less than two months later they arrived on the West coast, ready to start life together. ${ }^{27}$ How they managed to do that so quickly is the focus of the rest of her story. In the 1850s there were two ways to get to Oregon. One was by land over the Oregon Trail - the route taken by Mary Garrison Masters and her family. The other was by sea. If you had money, were in a hurry, and didn't mind getting seasick (or risking malaria, yellow fever, and cholera), going west by first going south was a good option - especially if you didn't plan to bring much with you. Being a newlywed, Sarah's trunk was most likely filled with her personal clothing and some essentials for starting a new home. Folded among the linens was undoubtedly her schoolgirl sampler, an object embedded with childhood memories and an important reminder of home and family. Given their speedy trip to the west coast, Sarah and Erasmus Shattuck definitely chose to travel by sea. Using a few known dates and the journals written by other female travelers it is possible to piece together most of the details of their journey.

After their wedding ceremonies Sarah and Erasmus left Vermont and traveled south to New York City, probably by train on the Central Vermont Railroad to New London, Connecticut and then on the newly finished Shore Line Railway from New London to New York City. On January $6,1853^{28}$ they boarded a ship bound for the isthmus of Panama and its Atlantic port of Colón (also called Aspinwall at the time), a voyage of about 2000 miles that usually took 11 to 13 days. According to the travel diary of Chastina Rix who also left Vermont in January of 1853 and traveled a similar route from Vermont to the West coast, the train tickets to New York cost

\footnotetext{
${ }^{25}$ Catalogue of the Officers and Students of the Bakersfield Academical Institution for the Year Ending November, 1848 (Burlington: Chauncy Goodrich, 1848), 24

${ }^{26}$ Catalogue of the Officers and Students of the Bakersfield Academical Institution for the Year Ending November 1849 (Burlington: Chauncy Goodrich, 1847), 14.

${ }^{27}$ Pioneer Index, Erasmus D. Shattuck. Portland, OR: Oregon Historical Society. The Oregon Historical Society maintains a card file on Oregon "pioneers"- travelers who settled in Oregon prior to the arrival of the transcontinental railroad in 1872. The card for Erasmus D. Shattuck lists the date of their departure from New York as January 6, 1853 and the date of their arrival in Portland as February 15, 1853 - a total of 41 days.

${ }^{28}$ Oregon Pioneer Index for William Masters, 1852.
} 
\$7.25 a piece and the steamer tickets to San Francisco each cost $\$ 305 .{ }^{29}$ After reaching Colón Sarah and Erasmus had to travel overland to cross the isthmus, a distance of approximately 60 miles. The first 25 miles could be achieved by taking the Panama Railroad where tickets were $\$ 8.00$ a piece. Although still under construction, the railroad could transport them as far as Barbacoas, where the ordeal of constructing a huge iron bridge able to withstand periodic flooding of the Chagres River had delayed laying rails any further. At this point travelers and their trunks were shifted to boats that were either polled or paddled up the Chagres River to Gorgona (usually an uncomfortable one-night stay) and then on to Las Cruces, a trip of about 20 miles. At Las Cruces decent hotels had been built to capitalize on the daily influx of travelers from the East, most heading to the gold fields of northern California.

The most uncomfortable part of the journey was yet to come - a trip of more than 15 miles over the Tabasará mountains to Panama City through dense, mosquito infested jungle terrain. Travelers had two choices - walk or hire a guide with mules. Sarah and Erasmus undoubtedly paid the $\$ 25.00$ each to make the trip by mule and another $\$ 20.00$ for each of their trunks to be transported in the same way. Once in Panama City (now called Old Panama) the task was to locate a steamer sailing to San Francisco - which could take weeks as shipping schedules were erratic at best. While waiting, travelers found that everything was extremely expensive, as even drinking water had to be transported into the city by mule. On the positive side, the stopover provided travelers an opportunity to take a bath, get clothing laundered, and purchase a few supplies for the upcoming voyage north to San Francisco.

Given the relatively short travel time recorded for their trip, it is safe to assume that Sarah and Erasmus were able to find a berth on a steamship heading north relatively quickly. Getting onto the ship, however, was described by diarists as both expensive and unpleasant, especially for female travelers. There were fees to be paid for everything, many of which were incurred because the city of Panama had no wharf - a fee for getting trunks from the hotel to the shore, a fee for loading the trunks onto a boat, a fee for having the boat rowed to the ship, and a fee for having yourself hoisted onto the shoulders of a "native" and carried onboard. Women often resisted the latter but had to comply when they realized there was no alternative. ${ }^{30}$ Once on ship there was yet another expense - having your ticket recorded. This allowed the ship's purser to alert the San Francisco newspapers, who in turn published the names of passengers and their anticipated arrival. The trip from Panama City to San Francisco was approximately 3000 miles and might include a stop in Acapulco. Although travel times varied, the trip took about two weeks.

There is no record of how long Sarah and Erasmus stayed in San Francisco (Figure 5) or the manner in which they traveled to Portland, but it was almost certainly by ship. There was no railroad between San Francisco and Portland at the time and overland travel relied on primitive roads that were either poorly maintained or nonexistent in the rainy month of February. In 1850 the Pacific Mail Steamship Company had been awarded a mail contract which resulted in regular passenger traffic between San Francisco and Portland, Oregon aboard either the Oregon or the

\footnotetext{
${ }^{29}$ Lynn A. Bonfield, "When Money was Necessary to Make Dreams Come True: The Cost of the Trip from Vermont to California via Panama." Vermont History, vol. 76, no 2. (2008), 134.

${ }^{30}$ Bonfield, 142-143.
} 
California. ${ }^{31}$ This was a comfortable option that the newlyweds probably selected for the final leg of their journey. The trip was about 650 miles and if all went well, took about five days.

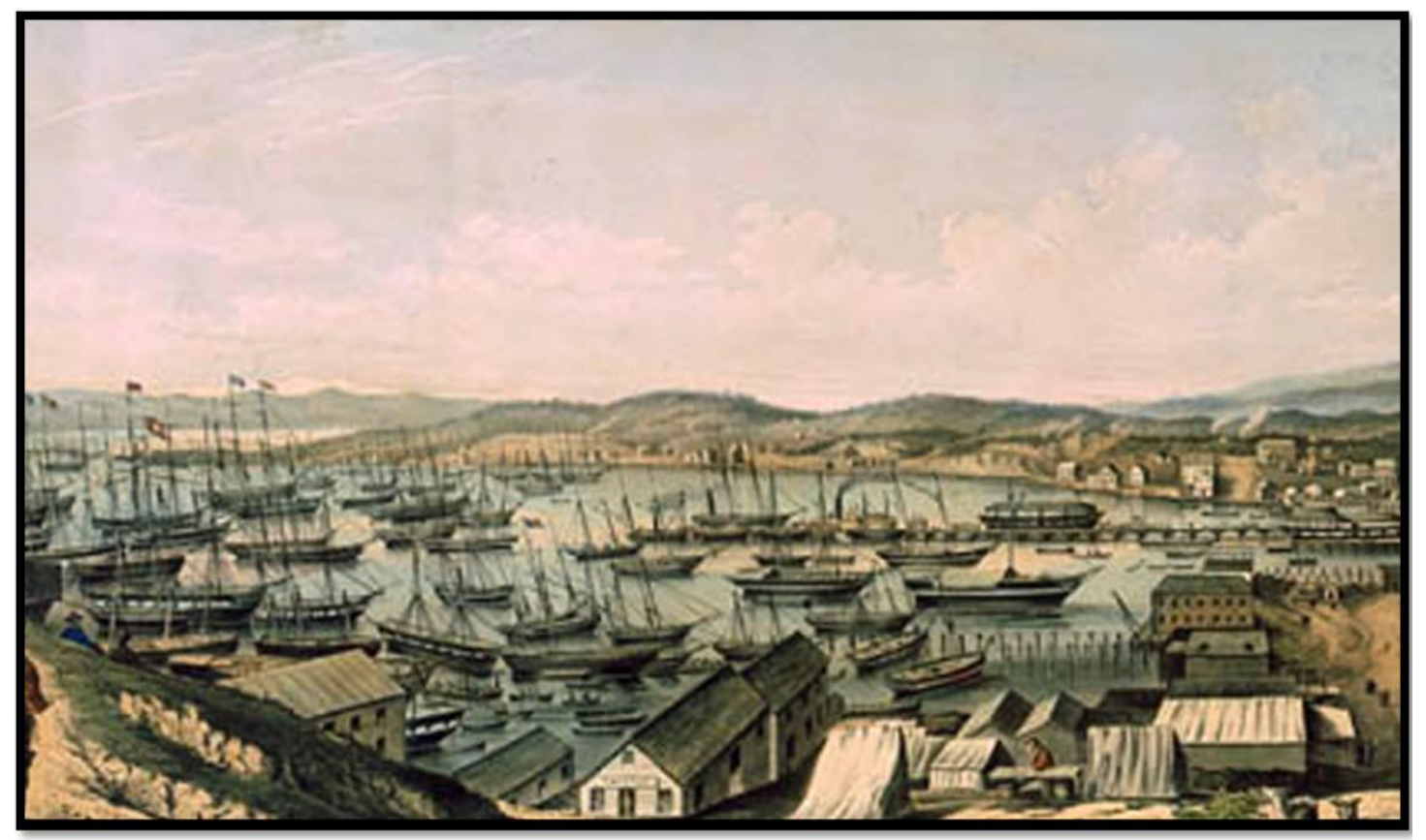

Figure 5. San Francisco harbor in 1853. Courtesy of the San Francisco Historical Society.

Sarah and Erasmus first settled in Oregon City, about 12 miles south of Portland along the Willamette River. Although it had been designated the capital of Oregon Territory in 1848, Oregon City's popularity with newcomers was on the decline. The capital had been moved to Salem in 1852 and Portland was assuming increased importance as a center for shipping and trade. Erasmus and Sarah followed the trend and by 1855 they had settled in Portland, where they remained. Like many highly educated young men in the sparsely populated new territory, Erasmus threw himself into diverse activities that served to advance educational, cultural, and political opportunities in their new home. Calling on his skills as an educator and his training as a lawyer Erasmus balanced a dizzying array of positions throughout his life. Upon arrival in 1853 he immediately secured a teaching position in a local school, becoming principal in 1854, and County Superintendent of Common Schools in 1855. After their move to Portland Erasmus opened a law practice and also accepted a position as professor of Latin and Greek at Pacific University in Forest Grove. In 1856 he became a probate judge for Washington County and in 1858 a Portland City Attorney. In 1861 and 1862 he served as a U.S. District Attorney for Oregon and then Judge for the Oregon Supreme Court from 1862 to 1867 and again from 1874 to 1878 . From 1886 to 1898 - two years before his death in 1900 - he served as Judge for the Fourth Judicial Circuit Court. ${ }^{32}$

In addition to his professional activities Erasmus got involved in Oregon politics. He was a "freestate delegate" to the Oregon Constitutional Convention in 1857, a Territorial Legislator in

\footnotetext{
${ }^{31}$ Richard H. Engeman, The Oregon Companion: An Historical Gazetteer of the Useful, the Curious, and the Arcane (Timber Press, 2009), 275.

${ }^{32}$ Sigma Phi, Catalogue of the Sigma Phi: E.P.V. (1891), 396.
} 
1858, and a member of the Portland City Council in 1859. He also co-founded the Portland Public Library and served as Director of the Portland Public Library Association beginning in $1864 .{ }^{33}$ In 1866 Erasmus became a trustee of the highly regarded Portland Academy and Female Seminary, a school whose structure and rigorous curriculum reflected that of his and Sarah's alma mater, Bakersfield Academical Institution. ${ }^{34}$ He also served on the school's Board of Trustees' Executive Committee for many years.

During this whirlwind of educational, political, legal, and community activity, there is no hint that Sarah Armstrong Shattuck drew upon her extensive education and training to become similarly engaged in the public sphere. Sarah's card in the Pioneer Index lists her occupation as "Housewife" and the 1870 federal census records her occupation as "Keeping house." That is not to imply that Sarah was not busy. On August 8, 1854 Sarah gave birth to their first child, Emily Shattuck. This was followed two years later by the birth of a son, Ira, and then another daughter, Bertha, two years after that. Their third son, Henry was born in 1861. After a respite of four years, Sarah and Erasmus had a fifth child, Lucy, and then their last, a son named Oscar. Of the six children born to Sarah and Erasmus, all but one (Bertha) would live to adulthood. However, only three would still be alive when Erasmus died on July 26, 1900 and Sarah died on December 2, 1902, both having reached the age of 75 .

At the time of their deaths, the Shattuck family home was a large, well-situated house in downtown Portland, a two-block walk from the courthouse and five blocks from the Willamette River. The 1870 federal census valued the home at $\$ 10,000$ and listed another $\$ 4000$ in Erasmus Shattuck's personal estate. Clearly Sarah and Erasmus did well in their new home in Portland, financially as well as personally. And their contributions, along with those of hundreds of other Oregon pioneers, are recognized for the impact they had on turning a primitive frontier town on the west coast into the thriving economic, cultural, and educational center it is today. Both Sarah and her husband Erasmus are buried in Portland's Lone Fir Pioneer Cemetery. Emily Shattuck, Sarah's oldest daughter, inherited the 1836 sampler Sarah embroidered in Vermont as a schoolgirl, and was responsible for its donation to the Oregon Historical Society.

\section{Concluding Remarks}

Through their needlework, we are able to catch a glimpse of Mary Garrison and Sarah Armstrong as schoolgirls, with unknown destinies. By uncovering the narrative threads of their lives, we learn something about them as adults - wives, mothers, and courageous female emigrants - willing to gamble that Oregon Territory held the key to family happiness, economic prosperity, and a permanent home. The stories embedded in their schoolgirl samplers - arduous travels by land and by sea - reveal something very profound about the role of textiles in our lives, the memories they carry, and the emotions they embody. Unframed, the samplers were tucked into the women's trunks, then loaded onto wagons, trains, ships, boats, and even mules to make their journeys westward. The fact that their schoolgirl samplers "made the cut" of what Mary and Sarah felt was essential to have with them when setting up a new home speaks volumes about the emotional value of girlhood needlework to these women. And the samplers' careful preservation is a testament to their importance and value as heirlooms to the families who inherited them.

\footnotetext{
${ }^{33}$ Sigma Phi, 396.

34 "Portland Academy and Female Seminary, 1851-1916," History of Education in Oregon (WPA, 1937), 64.
} 


\section{Select Bibliography}

Bonfield, Lynn A. "When Money was Necessary to Make Dreams Come True: The Cost of the Trip from Vermont to California via Panama." Vermont History, Vol. 76 (2), 2008, 130-148.

Catalogue of the Officers and Students of the Bakersfield Academical Institution. Burlington: Chauncy Goodrich, 1845, 1847, 1848, and 1849.

Engeman, Richard H. The Oregon Companion: An Historical Gazetteer of the Useful, the Curious, and the Arcane. Portland, OR: Timber Press, 2009.

Kingsley, Ben A. "History of the Town of Fletcher," Vermont Historical Gazetteer, Vol. 2, (1), $1871,200-217$.

Oregon Historical Society. Pioneer Index. Portland, OR: Oregon Historical Society, Index Collection. n.d.

Ring, Betty. Girlhood Embroidery: American Samplers \& Pictorial Needlework 1650-1850, Vol. 1. New York: Alfred A. Knopf, 1993.

Zoracki, Seth M. "Vermont's Tradition of Education and the Vermont Constitution." Albany Law Review, Vol. 67 (2), 2006, 581-590. 